Research Article

\title{
Experience and Challenges in Establishing Quarantine Facility for Suspected COVID- 19 Cases: Field Briefing
}

\author{
Shubha Garg', Akshay Kumar', Tushar Nale 3 , Navin Verma ${ }^{4}$, Meera Dhuria ${ }^{5}$, SK ]ain ${ }^{6}$, \\ Jugal Kishore ${ }^{7}$, Sujeet K Singh ${ }^{8}$
}

${ }^{1}$ Assistant Director, Division of Parasitic Diseases, NCDC, MHFW, Govt. of India, Civil Lines, New Delhi, India.

${ }^{2}$ Assistant Director, Centre for Environmental \& Occupational Health \& Climate Change, NCDC, MHFW, Govt. of India, Civil Lines, New Delhi, India.

${ }^{3}$ Assistant Director, Division of Zoonotic Diseases Programs, NCDC, MHFW, Govt. of India, Civil Lines, New Delhi, India.

${ }^{4}$ Assistant Director, Division of Non-Communicable Diseases, National Centre for Disease Control, Ministry of Health and Family Welfare, Govt of India, Civil Lines, New Delhi, India.

${ }^{5}$ Deputy Director, ${ }^{6}$ Additional Director, Division of Epidemiology, NCDC, MHFW, Govt. of India, Civil Lines, New Delhi, India. ${ }^{7}$ Professor \& Head, Department of Community Medicine, VMMC \& Safdarjung Hospital, New Delhi, India.

${ }^{8}$ Director, National Centre for Disease Control, Ministry of Health and Family Welfare, Govt of India, Civil Lines, New Delhi, India. DOI: https://doi.org/10.24321/2455.7048.202107

I $\quad \begin{array}{llll}\mathbf{N} & \mathbf{F} & \mathbf{O}\end{array}$

\section{Corresponding Author:}

Shubha Garg, Division of Parasitic Diseases, National Centre for Disease Control, Ministry of Health and Family Welfare, Govt of India, Civil Lines, New Delhi, India.

E-mail Id:

drshubhagarg@gmail.com

Orcid Id:

https://orcid.org/0000-0002-4187-6725

How to cite this article:

Garg S, Kumar A, Nale T, Verma N, Dhuria M, Jain SK, Kishore J, Singh SK. Experience and Challenges in Establishing Quarantine Facility for Suspected COVID-19 Cases: Field Briefing. Epidem Int. 2021; 6(3): 1-8.

Date of Submission: 2021-06-18

Date of Acceptance: 2021-07-07
$\begin{array}{llllllll}\mathbf{A} & \mathbf{B} & \mathbf{S} & \mathbf{T} & \mathbf{R} & \mathbf{A} & \mathbf{C} & \mathbf{T}\end{array}$

Introduction: Due to the unprecedented SARS-CoV-2 pandemic, in late January 2020, many countries in the world imposed a travel ban. Governments across the world initiated repatriation operations for stranded nationals. It was important to instantly develop quarantine facilities for evacuees. As the disease was fairly new, data on it was sparse to fulfil the requirement.

Objectives: We are sharing our experience of establishing and managing India's first quarantine facility for repatriate nationals focusing on key parameters including infection prevention and control, environmental cleaning, and bio-medical waste management along with basic living requirements.

Results: The facility housed a total of 617 evacuees from China and Italy. Among them, 17 were found to be positive on initial testing and one tested positive on the 14th day of testing. 25 contacts were traced and prescribed an additional quarantine period of fourteen days in the facility, and were discharged accordingly. All evacuees were put on community surveillance. Supply of logistics, manpower management, and ensuring compliance to protocols were some of the major challenges faced, for which appropriate actions were taken.

Conclusion: Impeccable collaboration and coordination among different stakeholders is the most essential ingredient for the successful operation of any quarantine facility in the context of the current pandemic.

Keywords: Quarantine Facility, India, Repatriate, COVID-19, Pandemic 


\section{Background}

In early January 2020, a novel coronavirus (2019-nCoV) was identified as the infectious agent causing an outbreak of viral pneumonia in Wuhan, China. The first few cases with symptoms, though, were traced in December 2019. ${ }^{1}$

Like wildfire, the infection spread globally and turned into an unprecedented pandemic. During the early stage of the pandemic, considering the SARS-CoV-2 crisis and its ability to transmit from human to human, ${ }^{2}$ many countries imposed travel restrictions and lockdown. Like other nations, the Indian government too planned repatriation of stranded Indian nationals from the infected countries.

On arrival to India, all repatriated nationals were prescribed mandatory institutional quarantine at a designated facility for a period of 14 days followed by self-quarantine for the same period.

As pioneers in establishing quarantine facility in India, by this communication, we intend to share our experience of managing such a facility for the repatriated nationals evacuated from China, Italy, etc. from February to April 2020.

\section{Selection of Facility and Infrastructure}

It was the early stage of the outbreak and there was a paucity of scientific evidence and literature specific to the natural history of disease and transmission dynamics of the infection. No approved guidelines were available for SARSCoV-2. Therefore, we relied on guidelines for evaluating homes and facilities for isolation and quarantine. ${ }^{3}$ We made a checklist for evaluating the quarantine facility. A newly constructed five-storey building of the Indo Tibetan Border Police (ITBP) was identified as a potential site for facility based quarantine. An expert team was constituted for the evaluation, based on criteria like location, accessibility, basic infrastructure, and available space. Since the ITBP building was on the outskirts of Delhi, in close vicinity of the international airport and had sufficient infrastructure and space, it fitted the locational requirement of a quarantine facility.

The original purpose of the building at ITBP Chawla Camp was to use it as a transit stay for 6 soldiers per barrack. The building had a capacity of accommodating 500 people with 100 on each floor. In order to maintain adequate distance between beds, three beds were arranged in each barrack and almost 32-42 evacuees per floor were housed with common toilets and bathrooms on each floor. Cohort mapping was done based on criteria such as family, gender (male/ female), history of travel to the epicentre (Wuhan/ non-Wuhan) etc. Ancillary services like reception, nursing station, room for donning/ doffing of Personal Protective Equipment (PPE), Closed-Circuit Television (CCTV) surveillance room, recreational activity hall, and holding area for bio-medical waste were provided on the ground floor. This building was cordoned off from other areas by fencing and deploying $24 \times 7$ security guards. A separate building in the campus housed the administrative office, control room, clerical room, logistics/storeroom, and lounge for doctors/ nurses and supporting staff.

\section{Logistic Support and Manpower}

Logistic support for equipment, materials required for sample collection, packaging and transportation, and laboratory support for COVID-19 testing including ambulance services were also provided. Human resource was arranged primarily from ITBP and from other agencies like state medical colleges and government hospitals for patient care and management, security, housekeeping services, meal preparation etc. Services had been provided free of cost round the clock by preparing duty rosters and engaging manpower accordingly.

\section{Capacity Building and Key Activities}

Furthermore, training was carried out for health care workers including doctors, nurses, paramedics, sanitary workers, and auxiliary staff focussing on standard precautions, hand washing, hand hygiene, cough etiquettes, respiratory hygiene, disinfection procedures, proper donning, doffing, and segregation and disposal of BioMedical Waste (BMW). Specific training of different teams was conducted in infection prevention and control practices with special reference to the COVID-19 virus according to their roles, responsibilities, and nature of duties. Whenever new staff joined the team, he/ she was trained at the earliest before commencing his/ her duties. Key activities mentioned in Table 1 were taken into consideration for the establishment of the quarantine facility, where utmost care and treatment could be provided to repatriated evacuees without compromising their own safety, and that of the health workers and their inmates.

\section{Screenings \& Repatriation}

Exit screening was conducted for all evacuees before boarding the repatriation flight. Entry screening for SARS-CoV-2 symptoms was conducted at Indira Gandhi International (IGI) airport by Airport Health Officials (APHO) in collaboration with other stakeholders (Figure 1). Every evacuee was being subjected to thermal screening. Suspected evacuees were isolated from others at the airport itself, examined by the Airport Medical Officer, and shifted to the isolation facility in dedicated ambulances if required. The rest of the evacuees were sent to the ITBP quarantine facility by buses. All vehicles used for transportation were disinfected with $1 \%$ sodium hypochlorite after each use. ${ }^{4}$ 
Table I.Summary of Key Activities considered for Setting up a Facility-based Quarantine in the context of COVID-I 9

\begin{tabular}{|c|c|c|c|c|}
\hline $\begin{array}{l}\text { S. } \\
\text { No. }\end{array}$ & Activity & Operational Considerations & Challenges & Actions Taken \\
\hline 1. & $\begin{array}{l}\text { Cohort and } \\
\text { lodging of } \\
\text { evacuees }\end{array}$ & $\begin{array}{l}3 \text { beds/ barrack, 32-42 } \\
\text { evacuees/ floor. } \\
\text { Common toilets and } \\
\text { bathrooms on each wing. } \\
\text { Separate buckets, mugs, } \\
\text { bathing and cloth rinsing } \\
\text { soap, liquid soaps for hand } \\
\text { washing, masks, sanitisers, } \\
\text { water bottles, electric kettles, } \\
\text { slippers, water jar etc. for } \\
\text { each evacuee. } \\
\text { Cohort mapping. }\end{array}$ & $\begin{array}{l}\text { Separate room with } \\
\text { attached toilet could not be } \\
\text { provided to each individual. } \\
\text { However, beds were kept at } \\
\text { a distance of } 1 \mathrm{~m} \text { and the } \\
\text { facility was naturally well } \\
\text { ventilated. } \\
\text { Compliance with social } \\
\text { distancing norms. } \\
\text { Minimising sharing of } \\
\text { articles. }\end{array}$ & $\begin{array}{l}\text { Advisory released for } \\
\text { evacuees. } \\
\text { Strict CCTV monitoring. } \\
\text { Public Address System } \\
\text { (PAS) used for immediate } \\
\text { intervention. } \\
\text { Signages like restricted } \\
\text { access and arrows were } \\
\text { used to display the } \\
\text { functional flow. }\end{array}$ \\
\hline 2. & Security & $\begin{array}{l}\text { Fencing and armed guards } \\
24 \times 7 . \\
\text { Record of in and out. } \\
\text { personnel at entry and exit } \\
\text { gate. } \\
\text { CCTV surveillance. }\end{array}$ & $\begin{array}{l}\text { Manpower rotation } \\
\text { for } 24 \times 7 \text { monitoring. } \\
\text { Maintenance of record. }\end{array}$ & $\begin{array}{l}\text { Supervisors appointed for } \\
\text { regular check. }\end{array}$ \\
\hline 3. & $\begin{array}{l}\text { Clinical } \\
\text { examination and } \\
\text { referral }\end{array}$ & $\begin{array}{l}\text { Done twice a day. } \\
\text { Two teams, each consisting } \\
\text { of a physician, resident, } \\
\text { nurse and paramedic staff for } \\
\text { morning shift, likewise one } \\
\text { team for evening and night } \\
\text { shift respectively on call. } \\
\text { Screened for fever, cough/ } \\
\text { sneezing, difficulty in } \\
\text { breathing and oxygen } \\
\text { desaturation. } \\
\text { Any suspect who manifested } \\
\text { symptoms at any point in time } \\
\text { was immediately referred } \\
\text { to the dedicated COVID-19 } \\
\text { isolation facility. }\end{array}$ & $\begin{array}{l}\text { PPE availability. } \\
\text { Supplies of medicine and } \\
\text { medical equipment. } \\
\text { Setting up Intercom } \\
\text { telephone lines on each } \\
\text { floor. } \\
\text { Setting up PAS on each } \\
\text { floor. } \\
\text { Vehicles for patient } \\
\text { transportation. }\end{array}$ & $\begin{array}{l}\text { Inventory maintained and } \\
\text { demand placed well in } \\
\text { advance. } \\
\text { Rational use of PPE } \\
\text { followed up. }{ }^{8} \\
\text { Improved communication } \\
\text { between stakeholders. }\end{array}$ \\
\hline 4. & $\begin{array}{c}\text { Sample } \\
\text { collection, } \\
\text { packaging, and } \\
\text { transportation }\end{array}$ & $\begin{array}{l}\text { Samples collected on day } 1 \\
\text { of arrival at the facility and at } \\
\text { the end of quarantine period } \\
\text { (14th day). } \\
\text { Transported in cold chain and } \\
\text { triple-layer packaging. } \\
\text { Any suspect who tested. } \\
\text { positive was immediately } \\
\text { referred to the dedicated } \\
\text { COVID-19 isolation facility. }\end{array}$ & $\begin{array}{l}\text { Supply of logistics, viz. } \\
\text { PPE, materials required } \\
\text { for sample collection, } \\
\text { packaging, and } \\
\text { transportation. } \\
\text { Skilled medical personnel. } \\
\text { Vehicles for transportation. }\end{array}$ & $\begin{array}{l}\text { Inventory maintained and } \\
\text { demand placed well in } \\
\text { advance. } \\
\text { Necessary training } \\
\text { incorporated. } \\
\text { Improved communication } \\
\text { between stakeholders. }\end{array}$ \\
\hline
\end{tabular}




\begin{tabular}{|c|c|c|c|c|}
\hline 5. & Food supply & $\begin{array}{l}\text { Separate entry for kitchen } \\
\text { staff. } \\
\text { Dining hall on each floor. } \\
\text { Disposable crockery and } \\
\text { cutlery. } \\
\text { Decontamination of non- } \\
\text { disposable articles. } \\
\text { Tables placed at } 1 \text { m distance } \\
\text { and reserved for single person } \\
\text { use. } \\
\text { Cleaning of furniture, floor, } \\
\text { water taps, and shared } \\
\text { utensils between two batches. }\end{array}$ & $\begin{array}{l}\text { Supplies of groceries. } \\
\text { Decontamination of non- } \\
\text { disposable articles. } \\
\text { Cleaning between two } \\
\text { batches. }\end{array}$ & $\begin{array}{l}\text { Protocol developed } \\
\text { for decontamination } \\
\text { procedure. } \\
\text { Supervision enhanced. }\end{array}$ \\
\hline 6. & $\begin{array}{l}\text { Mental health } \\
\text { and recreational } \\
\text { activity }\end{array}$ & $\begin{array}{l}\text { Wi-fi internet services. } \\
\text { Periodically counselling by } \\
\text { a clinical psychologist for } \\
\text { evacuees, medical and non- } \\
\text { medical teams. } \\
\text { Television and indoor games. }\end{array}$ & $\begin{array}{l}\text { Compliance with safe } \\
\text { distancing practices. }\end{array}$ & $\begin{array}{l}\text { Scope of television } \\
\text { was dismissed due } \\
\text { to violation of safe } \\
\text { distancing practices by } \\
\text { evacuees. }\end{array}$ \\
\hline 7. & $\begin{array}{c}\text { Infection } \\
\text { prevention and } \\
\text { control }^{4}\end{array}$ & $\begin{array}{l}\text { Training on proper donning, } \\
\text { doffing, and disposal of PPE, } \\
\text { standard precautions, hand } \\
\text { washing, hand hygiene, cough } \\
\text { etiquettes, and respiratory } \\
\text { hygiene. } \\
\text { Designated route for } \\
\text { movement. } \\
\text { Disinfection of medical } \\
\text { devices after usage.,9 } \\
\text { Disinfection of ambulances } \\
\text { after every use. } \\
\text { Removal of foot mats, } \\
\text { carpets, curtains, horticulture } \\
\text { decor stuff etc. } \\
\text { Foot-operated, covered } \\
\text { dustbin. }\end{array}$ & $\begin{array}{l}\text { Giving periodic training } \\
\text { especially whenever a new } \\
\text { member joined. } \\
\text { Supervision for } \\
\text { implementation of } \\
\text { protocols. } \\
\text { Disagreement with } \\
\text { guideline or specific } \\
\text { recommendations, lack of } \\
\text { commitment, motivation } \\
\text { and awareness. }\end{array}$ & $\begin{array}{l}\text { Capacity building of } \\
\text { trainers. } \\
\text { Supervisory team } \\
\text { consisting of a nursing } \\
\text { officer and a sanitisation } \\
\text { officer established for } \\
\text { regular supervision } \\
\text { and communication. } \\
\text { Counselling. }\end{array}$ \\
\hline 8. & $\begin{array}{l}\text { Environmental } \\
\text { cleaning }^{4}\end{array}$ & $\begin{array}{l}\text { Sweeping with broom was } \\
\text { avoided. } \\
\text { Mopping from the farthest } \\
\text { corner of a room to the exit } \\
\text { door. } \\
\text { Frequently touched surfaces } \\
\text { wiped with a damp cloth } \\
\text { daily. } \\
\text { Toilet floor, commodes, } \\
\text { washbasins, sink etc. cleaned } \\
\text { with } 1 \% \text { hypochlorite twice } \\
\text { daily. } \\
\text { Terminal cleaning between } \\
\text { two quarantined batches. }\end{array}$ & $\begin{array}{l}\text { Supplies of PPE (heavy- } \\
\text { duty rubber gloves and } \\
\text { gumboots). } \\
\text { Disinfection of tools used } \\
\text { for cleaning. } \\
\text { Supervision of cleaning, } \\
\text { hygiene, sanitation } \\
\text { methods. } \\
\text { RLU measurement in ATP } \\
\text { swab system or microbial } \\
\text { methods like aerobic colony } \\
\text { count and MRSA count } \\
\text { could not be exercised } \\
\text { for determination of the } \\
\text { efficacy of cleaning. }\end{array}$ & $\begin{array}{l}\text { Rational use of PPE } \\
\text { encouraged. } \\
\text { Checklist for cleaning and } \\
\text { disinfection was made } \\
\text { and accountability was } \\
\text { exercised. }\end{array}$ \\
\hline
\end{tabular}




\begin{tabular}{|c|c|c|c|c|}
\hline 9. & $\begin{array}{c}\text { Biomedical } \\
\text { waste (BMW) } \\
\text { management }{ }^{10,11}\end{array}$ & $\begin{array}{l}\text { Unidirectional route for } \\
\text { collection. } \\
\text { Collected thrice daily. } \\
\text { Storage area provided on } \\
\text { ground floor. } \\
\text { Surfaces of bins were } \\
\text { disinfected with } 1 \% \text { sodium } \\
\text { hypochlorite solution daily. } \\
\text { Common storage site was } \\
\text { cleaned once daily. } \\
\text { Ultimately outsourced for } \\
\text { final treatment and disposal } \\
\text { within } 24 \text { hours. }\end{array}$ & $\begin{array}{l}\text { Adequate PPE and training. } \\
\text { Foot-operated, covered } \\
\text { dustbin of suitable size with } \\
\text { colour coded polybags. } \\
\text { Disinfection of bins and } \\
\text { cleaning of storage area. }\end{array}$ & $\begin{array}{l}\text { Regular supplies ensured. } \\
\text { Capacity building of } \\
\text { trainers. } \\
\text { Checklist made for BMW. }\end{array}$ \\
\hline
\end{tabular}

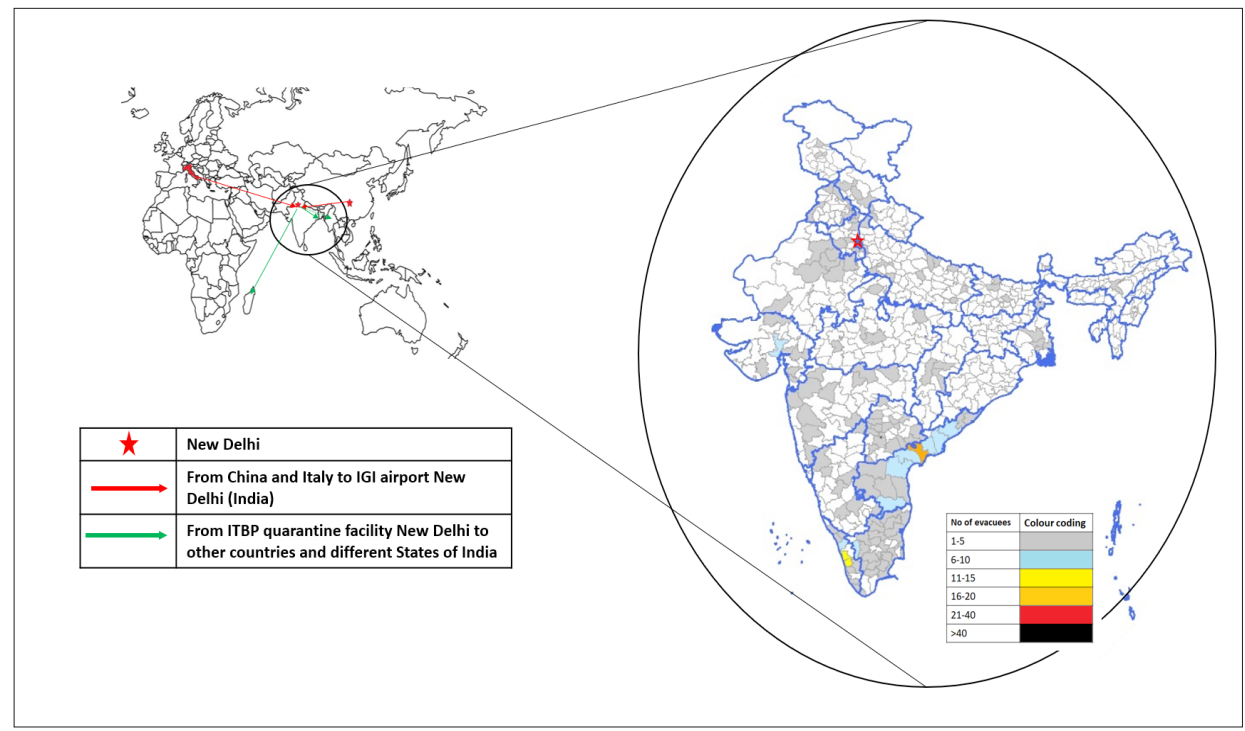

Figure I.Evacuation Flow of Repatriated Nationals from different Countries to India and their further discharge, except for Italian Tourist group with Indian Guide and Driver who were Repatriated from New Delhi, India, and further shifted to different COVID-I 9 Isolation Facilities

*Source: Adapted from Integrated Disease Surveillance Programme, India

Table 2.Demographic Characteristics and Period of Quarantine of Suspected

Cases of COVID-19 kept in Quarantine Facility

\begin{tabular}{|c|c|c|c|c|c|c|c|c|c|}
\hline \multirow[b]{2}{*}{$\begin{array}{l}\text { S. } \\
\text { No. }\end{array}$} & \multirow[b]{2}{*}{$\begin{array}{c}\text { Country of } \\
\text { Repatriation } \\
\mathrm{n} \text { (Total } \\
\text { Evacuees) }\end{array}$} & \multicolumn{2}{|c|}{ Quarantine Period } & \multirow[b]{2}{*}{$\begin{array}{l}\text { Age } \\
\text { (Years) }\end{array}$} & \multirow[b]{2}{*}{$\begin{array}{l}\text { Male } \\
\mathrm{n}(\%)\end{array}$} & \multirow[b]{2}{*}{$\begin{array}{c}\text { Female } \\
\text { n (\%) }\end{array}$} & \multicolumn{3}{|c|}{ Confirmed Cases\# } \\
\hline & & $\begin{array}{l}\text { Date of } \\
\text { Commen- } \\
\text { cement of } \\
\text { Quarantine }\end{array}$ & $\begin{array}{c}\text { Date of } \\
\text { Discharge (No. } \\
\text { of Evacuees } \\
\text { Discharged) }\end{array}$ & & & & $\begin{array}{c}\text { Asympto- } \\
\text { matic } \\
\mathrm{n}(\%)\end{array}$ & $\begin{array}{c}\text { Symptomatic } \\
\mathrm{n}(\%)\end{array}$ & $\begin{array}{l}\text { Total } \\
\text { n (\%) }\end{array}$ \\
\hline \multirow{5}{*}{1.} & \multirow{5}{*}{$\begin{array}{l}\text { China }^{\wedge} \\
(n=112)\end{array}$} & \multirow{5}{*}{$27-02-2020$} & \multirow{5}{*}{$\begin{array}{c}13-03-2020 \\
(112)\end{array}$} & $0-10$ & $4(3.6)$ & $1(0.9)$ & \multirow{5}{*}{$0(0)$} & \multirow{5}{*}{$0(0)$} & \multirow{5}{*}{$0(0)$} \\
\hline & & & & $11-20$ & $3(2.7)$ & $4(3.6)$ & & & \\
\hline & & & & $21-30$ & $\begin{array}{c}46 \\
(41.4)\end{array}$ & $\begin{array}{c}18 \\
(16.2)\end{array}$ & & & \\
\hline & & & & $31-40$ & $\begin{array}{c}21 \\
(18.9)\end{array}$ & $6(5.4)$ & & & \\
\hline & & & & $41-50$ & $7(6.3)$ & $2(1.8)$ & & & \\
\hline
\end{tabular}




\begin{tabular}{|c|c|c|c|c|c|c|c|c|c|}
\hline \multirow{5}{*}{2.} & \multirow{5}{*}{$\begin{array}{l}\text { India\$ } \\
(n=24)\end{array}$} & \multirow{5}{*}{ 03-03-2020 } & \multirow{5}{*}{$\begin{array}{c}04-03-2020 \\
(24)\end{array}$} & $35-40$ & $1(4.2)$ & $0(0)$ & \multirow{5}{*}{$15(62.5)$} & \multirow{5}{*}{$0(0)$} & \multirow{5}{*}{$\begin{array}{c}15 \\
(62.5)\end{array}$} \\
\hline & & & & $41-50$ & $0(0)$ & $2(8.4)$ & & & \\
\hline & & & & $51-60$ & $2(8.4)$ & $0(0)$ & & & \\
\hline & & & & $61-70$ & $5(21)$ & $5(21)$ & & & \\
\hline & & & & $71-80$ & $\begin{array}{c}3 \\
(12.6) \\
\end{array}$ & $6(25.2)$ & & & \\
\hline \multirow{6}{*}{3.} & \multirow{6}{*}{$\begin{array}{l}\text { Italy (Milan) } \\
(\mathrm{n}=218)\end{array}$} & \multirow{6}{*}{$\begin{array}{c}16-03-2020 \\
\text { (for contacts) }\end{array}$} & \multirow{6}{*}{$\begin{array}{c}29-03-2020 \\
(211)\end{array}$} & $11-20$ & $3(1.3)$ & $3(1.3)$ & \multirow{6}{*}{$\begin{array}{c}1+1^{*} \\
(0.9)\end{array}$} & \multirow{6}{*}{$0(0)$} & \multirow{6}{*}{$\begin{array}{c}2 \\
(0.9)\end{array}$} \\
\hline & & & & $21-30$ & $\begin{array}{c}142 \\
(65.1)\end{array}$ & $58(26.6)$ & & & \\
\hline & & & & $31-40$ & $8(3.7)$ & $2(0.9)$ & & & \\
\hline & & & & $41-50$ & $0(0)$ & $0(0)$ & & & \\
\hline & & & & $51-60$ & $0(0)$ & $1(0.5)$ & & & \\
\hline & & & & $>60$ & $1(0.5)$ & $0(0)$ & & & \\
\hline \multirow{6}{*}{4.} & \multirow{6}{*}{$\begin{array}{l}\text { Italy (Rome) } \\
(\mathrm{n}=263)\end{array}$} & \multirow{6}{*}{$\begin{array}{l}05-04-2020 \\
\text { (for contacts) }\end{array}$} & \multirow{3}{*}{$\begin{array}{c}04-04-2020 \\
(244)\end{array}$} & $0-10$ & $1(0.4)$ & $0(0)$ & \multirow{6}{*}{$1(0.4)$} & \multirow{6}{*}{$0(0)$} & \multirow{6}{*}{$\begin{array}{c}1 \\
(0.4)\end{array}$} \\
\hline & & & & $11-20$ & $\begin{array}{c}15 \\
(5.7) \\
\end{array}$ & 5 (1.9) & & & \\
\hline & & & & $21-30$ & $\begin{array}{c}178 \\
(67.7) \\
\end{array}$ & $\begin{array}{c}44 \\
(16.7) \\
\end{array}$ & & & \\
\hline & & & \multirow{3}{*}{$\begin{array}{c}18-04-2020 \\
(18)\end{array}$} & $31-40$ & $\begin{array}{c}10 \\
(3.8)\end{array}$ & $4(1.5)$ & & & \\
\hline & & & & $41-50$ & $3(1.1)$ & $2(0.8)$ & & & \\
\hline & & & & $51-60$ & $1(0.4)$ & $0(0)$ & & & \\
\hline
\end{tabular}

\# confirmed cases discharged to their respective states/ country from isolation facility

$\wedge 55$ had a history of travel to Wuhan.

\$21 Italian tourists +3 Indians (guide, driver, and conductor)

*1 confirmed case gave a history of fever 3-4 days ago, though was asymptomatic at the time of testing

A total of 617 Indian and other nationals were repatriated between February and April, 2020. Out of these, 112 (18.15\%) evacuees were from Wuhan and non-Wuhan provinces of China, 24 (3.89\%) were from India [21 were Italian tourists and 3 Indians (guide, driver, and conductor)], 218 (35.33\%) were from Milan, Italy, and 263 (42.63\%) were from Rome, Italy (Table 2).

\section{Clinical Examination, Testing and Referral}

On arrival at the quarantine facility, a baseline medical examination of each evacuee was done by the medical team. On the first day of arrival to the facility, regardless of clinical symptoms, all evacuees were tested for SARSCoV-2 by Reverse Transcription Polymerase Chain Reaction (RT-PCR). For the next 14 days, evacuees were examined twice daily by medical teams for the development of symptoms suggestive of SARS-CoV-2 (Table 1). Evacuees who were found to be positive during initial testing or manifested clinical features of COVID-19 at any point in time during the quarantine period, were immediately transferred to the dedicated COVID-19 isolation facility for further management and were discharged from there only. Total $17(2.75 \%)$ evacuees were found positive on initial testing including 14 Italian tourists, their Indian guide, and 2 repatriate Indian nationals from Milan. COVID-19 positive Indian guide and 2 Indian nationals (driver and conductor) were immediately transferred to a designated tertiary care hospital for isolation. 14 Italian tourists who tested positive for SARS-CoV-2 and the rest of the 7 Italians were transferred to a reputed private tertiary care hospital in Gurugram in separate vehicles.

After completion of the specified quarantine period, the evacuees were again tested through RT-PCR on the 14th day and were discharged after testing negative. Since evacuees from Rome had already been tested just before the evacuation activity, hence they were retested only at the end of the quarantine period. Among them, only one $(0.16 \%)$ evacuee from Rome tested positive.

\section{Contact Tracing and Reset of Quarantine}

Whenever confirmed SARS-CoV-2 positive cases were 
recognised, contact tracing was initiated. Close seating in aircraft, sharing the same barrack, handshaking, sharing of personal articles, dining at the same table or any activity where the person was within $1 \mathrm{~m}$ distance with a confirmed case was considered as high-risk exposure. ${ }^{5}$ To facilitate contact tracing, photographs of positive cases were used and interviews of passengers and telephonic interviews of positive cases were taken to determine the level of exposure of an individual. Among the evacuees from Milan, 5 were identified as close contacts where 4 shared the same barrack and 1 shared a dining table with a confirmed case. Likewise, 18 evacuees from Rome were identified as close contact where 2 were in the same barrack, 1 shared a personal article (laptop), and 15 had exposure during recreational activities. A 14-day quarantine period was reset for them from the day of last contact with a confirmed SARS-CoV-2 case (Table 1). Exposure risk assessment among Health Care Workers (HCWs) who were involved in routine clinical examination, sample collection, packaging and transportation, was done according to World Health Organization (WHO) protocol. ${ }^{6}$ They were found to be at low risk for SARS-CoV-2 infection, and hence were advised self-monitoring of temperature and respiratory symptoms daily for 14 days from the last day of exposure and precautions against contact, droplet, and airborne spread wherever required.

\section{Discharge and Community Surveillance}

After completion of 14 days quarantine period, the evacuees who tested negative for SARS-CoV-2 infection through RTPCR were discharged to their respective states/ districts (Figure 1). Details of their stay for the next 14 days including contact numbers were obtained from the passengers before discharging them from the ITBP quarantine facility. Advisory about home quarantine and the recommendations of self-monitoring of their health, practising hand-washing, hand hygiene, and wearing masks were shared with them. State Surveillance Officer's/ District Surveillance Officer's (SSO/ DSO) numbers were provided to them to report in case of any health issue. Integrated Disease Surveillance Programme (IDSP), State units were directed to put them on community surveillance for the next 14 days.

Fortunately, none of the evacuees developed symptoms after discharge. Monitoring and supervision were done by an expert team and senior officials from the Ministry of Health and Family Welfare (MoH\&FW) by regular visits.

\section{Challenges and Action Taken}

In the present study, we have tried to share our experience of establishing and running the very first quarantine facility of India for repatriated nationals. Reasons for successful or unsuccessful operation of any facility are often multiple and interconnected. And so, challenges are a universal part of human experience.
Arrangement and supply of logistics viz. PPE, materials required for sample collection, packaging and transportation, medicines, medical equipment, grocery for meal preparation, vehicles for transportation etc. was a leading hindrance in the successful running of the facility. Since the facility was situated in the outskirts of the city, transportation and commute cost was significantly high due to distance, thereby leading to increased consumption of fuel.

Manpower management was another challenge. The intent was to retain the same members in a team for the complete quarantine period which could not be achieved due to fear among workers or their family members about their health and well-being. Training and quality communication with them were an essential requirement which was handled in a solution-oriented effective way. Psychosocial counselling was also conducted whenever required. Steps to ensure compliance to protocols and recommendations among HCW and evacuees, a key parameter for a successful quarantine facility, were put in place. Disagreement with the guidelines or specific recommendations, lack of commitment, motivation and awareness led to suboptimal compliance to recommendations by individuals. When used alone, printed information and educational material generally led to limited improvement in practices. However, implementation of and compliance with the recommendations improved with communication. Round the clock surveillance with CCTV cameras and public address system were established on each floor to improve communication with evacuees and provide necessary instructions. Signages like restricted access and arrows to display functional flow were pasted to minimise the interaction between $\mathrm{HCW}$ and quarantined inhabitants. Since CCTV cameras could not be installed in bathrooms and toilet areas, hence their demarcated use could not be ensured (Table 1).

Routine evaluation of cleaning, hygiene, and sanitation methods was ensured by a supervisory team. Determination of efficacy of cleaning method was tough and subjective by mere visual inspection of the cleaned area. ${ }^{7}$ Other chemical methods like Relative Light Units (RLU) measurement in ATP swab system or microbial methods like aerobic colony count and MRSA count could not be exercised due to limitations of resources in field settings.

\section{Ethical Approval and Consent to Participate}

This was a public health response from the Ministry of Health \& Family Welfare, Government of India, undertaken with the purpose to prevent the spread of SARS-CoV-2 in India. Nasal and throat swabs were taken from evacuees to screen them for the infection of SARS-CoV-2. Ethical approval is not applicable as part of public health response. All ethical principles and guidelines of the Government of India were adopted during the outbreak response: the investigation was aimed at achieving public good (beneficence) and 
collective welfare (solidarity); no harm was done to any individual (non-maleficence); the whole process was fair, honest, and transparent (accountability and transparency); and participants' data were de-identified prior to analysis (confidentiality). This study involves secondary data analysis and hence no consent was taken.

\section{Conclusion}

While establishing and running the very first quarantine facility of India, we faced many challenges, primarily supply of logistics, manpower management, and poor compliance to protocols. The passive presence of written guidelines/ SOPs is not sufficient to establish a quarantine facility. Committed leadership, improvement in collaborations, coordination between different stakeholders, transparency between key partners, regular supplies of logistics, dedicated and skilled manpower, general and task-oriented training and development at multi-disciplinary approach, motivation, and awareness are the most essential ingredients for the successful operation of a quarantine facility for suspected cases of COVID-19 in the current pandemic.

\section{Acknowledgement}

We acknowledge the contribution of ITBP's medical, paramedical, support staff in establishing and maintaining the quarantine facility.

\section{Source of Funding: None \\ Conflict of Interest: None \\ References}

1. World Health Organization (WHO) [Internet]. WHO Statement Regarding Cluster of Pneumonia Cases in Wuhan, China. Beijing: WHO; 2020 Jan 9 [cited 2020 Jun 9]. Available from: https://www.who.int/china/ news/detail/09-01-2020-who-statement-regardingcluster-of-pneumonia-cases-in-wuhan-china

2. Li Q, Guan X, Wu P, Wang X, Zhou L, Tong Y, Ren R, Leung KSM, Lau EH, Wong JY, Xing X, Xiang N, Wu Y, Li C, Chen Q, Li D, Liu T, Zhao J, Liu M, Tu W, Chen C, Jin L, Yang R, Wang Q, Zhou S, Wang R, Liu H, Luo Y, Liu Y, Shao G, Li H, Tao Z, Yang Y, Deng Z, Liu B, Ma Z, Zhang Y, Shi G, Lam TTY, Wu JT, Gao GF, Cowling BJ, Yang B, Leung BM, Feng Z. Early transmission dynamics in Wuhan, China, of novel coronavirus-infected pneumonia. N Engl J Med. 2020 Mar 26;382(13):1199-207. [PubMed] [Google Scholar]

3. Centers for Disease Control and Prevention [Internet]. Severe acute respiratory syndrome: Guidelines for evaluating homes and facilities for isolation and quarantine; [cited $2020 \mathrm{Jul}$ 9]. Available from: https:// www.cdc.gov/sars/guidance/d-quarantine/app3.html

4. National Centre for Disease Control [Internet]. National guidelines for infection prevention and control in healthcare facilities. Directorate General of Health Services, Ministry of Health and Family Welfare, Government of India; [cited 2020 Jul 9]. Available from: https://www.mohfw.gov.in/pdf/National\%20 Guidelines\%20for\%20IPC\%20in\%20HCF\%20-\%20 final\%281\%29.pdf

5. National Centre for Disease Control [Internet]. The updated case definitions and contact-categorisation. Directorate General of Health Services, Ministry of Health and Family Welfare, Government of India; 2020 January [cited $2020 \mathrm{Jul}$ 9]. Available from: https://ncdc. gov.in/WriteReadData/l892s/89568514191583491940. pdf

6. World Health Organization (WHO) [Internet]. Health workers exposure risk assessment and management in the context of COVID-19 virus: Interim guidance, 4 March 2020; [cited 2020 Jul 9]. Available from: https:// apps.who.int/iris/handle/10665/331340

7. Sherlock O, O'Connell N, Creamer E, Humphreys H. Is it really clean? An evaluation of the efficacy of four methods for determining hospital cleanliness. J Hosp Infect. 2009 Jun;72(2):140-6. [PubMed] [Google Scholar]

8. Ministry of Health and Family Welfare [Internet]. Novel Coronavirus Disease 2019 (COVID-19): Guidelines on rational use of Personal Protective Equipment. Ministry of Health and Family Welfare, Directorate General of Health Services [Emergency Medical Relief]; [cited $2020 \mathrm{Jul}$ 9]. Available from: https://www.mohfw.gov. in/pdf/guidelinesonrationaluseofPersonalProtective Equipment.pdf

9. Spaulding E. The role of chemical disinfection in the prevention of nosocomial infections. In: Proceedings of the International Conference on Nosocomial Infections, 1970. Chicago, IL: American Hospital Association; 1971;247-54.

10. India Environment Portal [Internet]. The bio-medical waste management (amendment) rules, 2018; [cited 2020 Jul 9]. Available from: http://www. indiaenvironmentportal.org.in/content/453336/ the-bio-medical-waste-management-amendmentrules-2018/

11. Central Pollution Control Board [Internet]. Guidelines for handling, treatment and disposal of waste generated during treatment/diagnosis/ quarantine of COVID-19 Patients (In suppression earlier guidelines upload at CPCB website on 19/03/2020). Central Pollution Control Board, Ministry of Environment, Forest \& Climate Change; 2020 Mar 25 [cited 2020 Jul 9]. Available from: https://www.mohfw.gov.in/ pdf/63948609501585568987wastesguidelines.pdf 